Book Review: David Skarbek, The Puzzle of Prison Order: Why Life Behind Bars Varies Around the World. New York: Oxford University Press. 2021. ISBN 978-0-19-067250-8 (Paperback). 220 Pages. \$27.95.

\author{
Reviewed by Mitchel P. Roth ${ }^{1}$
}

[Article copies available for a fee from The Transformative Studies Institute. E-mail address: journal@transformativestudies.org Website: http://www.transformativestudies.org (C2022 by The Transformative Studies Institute. All rights reserved.]

David Skarbek's book, The Puzzle of Prison Order, is a welcome addition to a growing body of work on prisons from a comparative perspective. It makes an important contribution to academic debates on prison social order. Global and historical scope, it covers prisons from a Confederate prisoner of war camp housing Union soldiers at Andersonville during the last years of the Civil War to modern women's prisons in California and a gay and transgender housing unit in the Los Angeles County Jail system, the country's largest jail system. In between, Skarbek offers case studies of prison governance in Brazil and Bolivia, where prisoners virtually run the prison systems, Nordic prisons where the officials are in complete control, and social networks within English prison systems.

\footnotetext{
${ }^{1}$ Mitchel Roth is a Professor of Criminal Justice and Criminology at Sam Houston State University. His areas of interest include the global organized crime and gangs, history of crime and punishment, mass murder and serial homicide and mass murder. He has written many books on a variety of topics. His most recent books include Power on the Inside: A Global History of Prison Gangs (2020) Fire in the Big House: The Worst Prison Disaster in American History (2019), The Illicit Economy in Turkey (with Mahmut Cengiz) (2019), A History of Crime and the American Criminal Justice System (2018), An Eye for An Eye: A Global History of Crime and Punishment (2015) and Convict Cowboys: The Untold History of the Texas Prison Rodeo (2016). He is editor-in-chief of the International Journal of Criminology and Sociology. His books have been translated into Chinese, Persian, Croatian and Turkish. He has been an instructor at the Zhejiang Police College from 2009 to 2019 and at the International Law Enforcement Academy (Roswell) from 2001-2009. Roth has appeared on or been featured on the Travel Channel, CNN, FOX, Al Jazeera, the History Channel, PBS and other media programs. In 2020 Dr. Roth was awarded the Frederic Milton Thrasher for excellence in gang research.
} 
This book is a natural extension of his research that produced the 2014 book, The Social Order of the Underworld: How Prison Gangs Govern the American Penal System (New York: Oxford), which examined prison governance, both formal and informal, through the activities of prison gangs in various parts of the world. As an historian, the reviewer appreciates the inclusion of historical research methods, so lacking in most academic works on penology. Not only does it enhance the knowledge base of the reader but it's contextualization of why prison life around the world differs is an eye-opener to anyone interested in learning more about prison governance.

Skarbek begins his examination by chronicling the various problems of keeping order in prisons, wherever they may be. Moreover, "The same needs for governance that exist throughout society also arise in prison (7)." The author makes distinctions between "four ideal types of governance regimes, based on who produces the governance." These include official governance, co-governance, self-governance, and minimal governance. In an endnote, Skarbek explains that these four categories "are not meant to be mutually exclusive and exhaustive," noting how prison regimes can evolve over time and that there are "other cases that might not fit these categories and will be hybrid cases (170, N28)." Chapters of case studies are devoted to each one.

Chapter two focuses on Brazil and Bolivia, where the correctional profession is leaps and bounds behind the United States. As a result, the prison trends in these countries do not follow the same trends in other countries with expanding prison populations. He compares U.S. prisons, where there has been a significant decline in the extent prisoners help run U.S. prisons over the past seventy years, to Brazil, where inmates often play a central role in the running of a prison's daily operations. Likewise, Bolivia's San Pedro Prison exemplifies an institution where the prisoners "are responsible for essentially all prison services (32)."

Chapter three, on "Nordic Exceptionalism," covers Scandinavia (Denmark, Norway, and Sweden), as well as Finland, Iceland, Greenland, and the Faeroe Islands, all countries with smaller prisons, where there tends to be less victimization than in their larger counterparts elsewhere. Skarbek acknowledges that some of his claims have been regarded as "overstated" and "incomplete" by some Nordic prison scholars, but it does not take away from the fact that these prisons have a "radically different quality of governance" compared to many prisons in the Americas (176 N45).

Chapter four covers the Andersonville prison camp in 1864-1865, where it seems no one governed. More broadly, this prison has been 


\section{Mitchel Roth}

utilized as "a case study in systems failure (63)." This chapter is especially noteworthy because it make a strong case that Skarbek's governance framework can be applied in both contemporary settings and in historical cases as well. Indeed, it is well known that neither prisoners nor officials provided governance to the detriment of thousands of prisoners (nearly $30 \%$ of the 45,000 prisoners) who perished from the elements and murderous inmate gangs. This case study offers an excellent example of how in some instances, prison governance institutions fail to develop. Among the more tantalizing findings is the fact that unlike modern prisons, where friends and family members smuggle in life-sustaining contraband to the prisoners, the prisoners at Andersonville lived in an isolated economy where friends and work details outside the prison were strictly limited. Likewise, when a prisoner had at least ten friends when he entered the camp, he was more likely to survive than others who did not (70).

Chapters five through seven cover prisons where the "the quality of official governance is neither extremely high nor low (89)." These include women's prisons in California, English prisons and the gay and transgender housing unit in the Los Angeles County jail system. In these settings, Skarbek suggests that official governance in these institutions fall within a more moderate range, not as good as the Nordic system and much better than many Latin American prisons.

Ultimately, The Puzzle of Prison Order demonstrates that all prisons share "fundamental similarities" starting with the fact that they house individuals charged or convicted of crimes. This book will be of interest to scholars and the general reading public. Its multidisciplinary approach can be a model for future comparative research. Well-written and jargon free it is accessible to anyone interested learning more about the world's prison systems. 